\title{
Vocational High School Female Students' Opinions About Application Level of Skill Education
}

\author{
Gülçin ÜSTÜN* Duygu SAVAŞ**
}

\begin{abstract}
Vocational Education Law was put into practice in 1986 to make the execution of vocational education in accordance with the needs and demands of work life. Applications of this new skill education framework were developed quickly. However, examinations and evaluations on vocational education show that skill education practices running in enterprises were incomplete or incorrect. The purpose of this study is to analyze application level of the vocational education given in school/company and enterprises in accordance with Vocational Education Law. 138 senior level students from four different vocational high schools in Ankara were randomly selected and included in this study. Data were collected using survey and scanning methods. Statistical Package for Social Sciences (SPSS) was used to analyze data. Results show that participants were satisfied with the skill education given in enterprises. Data also suggested that an effective communication was needed between school and enterprises to be able to put new skill education requirements in order improving the quality of work force.
\end{abstract}

Key Words: Skill education in enterprises, vocational education, Laws 3308 and 4702

\footnotetext{
Correspondence, Assoc. Prof. Dr., Gazi University Vocational Education Faculty, Department of Clothing Industry and Fashion Design, gustun@gazi.edu.tr

** Teacher, Ankara Maturation Institute, Department of Fashion Design, dsavas76@yahoo.com
} 


\section{SUMMARY}

Development of new technologies in world and utilization of new materials in industry made many industrialized countries look through their level of technical personnel capability and structure. Today, enterprises that exist in our developing country remain inadequate compared to international standards even if they can answer the needs of the domestic market in the sense of quantity and capacity. Therefore, to catch the standards of developed countries, the quality of work power of Turkey needs to be increased first.

Execution of educational activities is an indispensable necessity in order to catch up with technological developments and relevant changes. Therefore, industry and education, especially vocational education, completes each other. In 1986, Vocational Education Law, number 3308, was put into practice to make the execution of vocational education in accordance with the needs and demands of work life, based on school/company-workplace collaborated education basis in a participant sense and to develop the vocational and technical education system in order to raise its quality to the contemporary standards. Vocational education practice that is brought to schools/companies and enterprises by means of this law is carried on progressively. Nevertheless, examinations and evaluations about vocational education carried out on school/companies and enterprises done by Ministry of National Education (MNE Notice 2006/12) and some other scientific researches show that skill education practices running in enterprises are carried out incomplete, different and faulty.

It is observed from the study that students marked good for the entry \#1 about "Teaching of the vocational knowledge in school before starting the skill education" and also the general averages vary inside these boundaries. When the entry \#2 about "Evaluation of the chosen enterprise about administrator attitude, master instructor's approach, technologic level and location" is examined, it is found out that $69.4 \%$ of the participants picked the "good" and "very good" options. When the entry \#3 about "Proper timing of the correspondences, contracts and meetings between the school, employer and the responsible parent" is examined, it is observed that students state that these processes are executed at the "good" level.

It is deduced from the students' answers to the table entry \#4 about "Carrying out of the students' insurance operations without any problem" that this process is completed at the "good" level. Similarly, the process related with the entry \#5 about "Preparation of the education plan which includes the subjects that the students need to learn during skill education by 
the instructor" is completed at the "good" level. However, the information collected from the entry \#6 about "Guiding of the students and the enterprises about skill education by the school" show that this duty is carried out at the "intermediate" level by the responsible individuals.

Results from table entries \#7 and \#8 which measure the fulfilling degree of the regulations are found out to be at the "intermediate" level. Nevertheless, it is interesting that the process related with the entry \#10 about "Level of the machine-tool using skill gained by the students in relevance with the departments in the enterprises" is accomplished at the "good" level. The answers to the entry \#9 about "Monitoring of the students' vocational development by making use of the development tables" point out that this process is carried through at the "good" level.

The entry \#12 about "Regular examination level of the students' attendance by the enterprise" was evaluated as "very good" by more than the half of the students. It is also observed that the entry \#17 about "Regular investigation of the students' disciplinary state by the school and the enterprises" and the entry \#19 about "Regular visitation of the enterprises by the school and continuing of the inspections" are executed at the "good" level. The information point out that the school and the enterprises consider the supervision and discipline subjects seriously and that these regulations are carried out as much as possible.

The results regarding the table entry \#20 about "Regular investigation of the student's states of attendance, achievement and discipline" show that this process is accomplished at the "good" level too.The data obtained from the table entry \#21 about "Carrying out of the student evaluation by means of the final skill exams applied by the school" are also at the "good" level. The connection between education foundations and enterprises should not be just composed of fulfilling of relevant laws. It is in our national interests to form a continuous relation based on developing each other between these two partners. 


\title{
İşletmelerde Yapılan Beceri Eğitiminin Amacına ve Mesleki Eğitim Yönetmeliği Hükümlerine Göre Uygulanma Düzeyi Hakkında Kız Meslek Lisesi Öğrencilerinin Görüşleri
}

\author{
Gülçin ÜSTÜN* \\ Duygu SAVAŞ
}

ÖZ. Ülkemizde mesleki eğitimin iş hayatının ihtiyaç ve talepleri doğrultusunda, okul/kurum-işyeri ortaklaşa eğitim esasına dayalı, katılımcı bir anlayışla yapılması, mesleki ve teknik eğitim sisteminin geliştirilerek kalitesinin çağdaş standartlara yükseltilebilmesi amacıyla 1986 yllında 3308 sayılı Mesleki Eğitim Kanunu uygulamaya konulmuştur. Ancak, okul/kurum ve işletmelerde meslek eğitimi ile ilgili olarak hem Milli Eğitim Bakanlığının yaptığı inceleme ve değerlendirmeler sonucunda hem de yürütülen bazı bilimsel araştırmalar sonucunda işletmelerde beceri eğitimi uygulamalarında eksik, farklı ve hatalı uygulamaların yapıldığı tespit edilmiştir. Çalışma, okul/kurum ve işletmelerde yapılan mesleki eğitimin, 3308 sayılı Mesleki Eğitim Kanunu hükümlerine göre uygulanma düzeyini belirlemeyi amaçlamaktadır. Araştırma kapsamına 4 adet Anadolu Kız Meslek ve Kız Meslek Lisesinin Tekstil-Konfeksiyon dalı 138 son sınıf öğrencisi tesadüfi örnekleme yöntemi ile alınmıştır. Konuyla ilgili veriler anket tekniği ile toplanmıştır. Verilerin çözümlenmesinde, SPSS (Statistical Package for Social Science) istatistik programından yararlanılmıştır. Araştırma öğrencilerin beceri eğitimi uygulamalarına karşı olumlu bir tavır içerisinde olduğunu göstermiş̦tir. Türkiye'de ki nitelikli iş gücü yetiştirilmesindeki gelişmeyi sürdürmek ve bunu daha ileri noktalara ulaştırmamız yeni ihtiyaçlar doğrultusunda okul-işletme diyoloğunun etkili bir şekilde yürütülmesi gerekmektedir.

Anahtar Sözcükler: İşletmelerde beceri eğitimi, mesleki eğitim, 3308 ve 4702 sayılı Kanunlar

\footnotetext{
* Yrd. Doç. Dr. Gazi Üniversitesi Mesleki Eğitim Fakültesi, Giyim Endüstrisi ve Moda Tasarımı Eğitimi Bölümü Öğretim Üyesi gustun@gazi.edu.tr, gulcin_ustun@yahoo.com ${ }^{* *}$ K.T.Ö. Ankara Olgunlaşma Enstitüsü, Moda Tasarımı Bölümü Öğretmeni dsavas76@yahoo.com
} 


\section{GíRiş}

Eğitim sisteminin en önemli amaçlarında biri, iş gücü piyasasının ihtiyaç duyduğu nitelikte istihdam edilebilir bireylerin yetiştirilmesidir. Bu sistem içerisinde özellikle Mesleki ve Teknik Eğitim, kişinin mevcut potansiyelini ve yeteneklerini geliştiren, ona üretkenlik niteliği kazandıran çok önemli bir yere sahiptir. Çünkü temel mesleki bilgi ve becerilere sahip, gelişken ve değişken teknolojiden haberdar, yeni durumlara kolay ve hızla uyum sağlayan nitelikli eğitilmiş ve istihdam edilmiş iş gücünü yaratmada bu kurumlar stratejik önem taşımaktadır. Bu yüzden kalkınma planları, Milli Eğitim şura kararları ve hükümet programlarında mesleki teknik eğitim, titizlikle üzerinde durulan konuların başında gelmektedir.

Ancak Türkiye'de uygulanan mesleki eğitim sistemine bakıldığında, nitelikli işgücünü oluşturmaya yönelik çabaların tam anlamılla gerçekleşmediği de dikkat çekmektedir. Cumhuriyetle birlikte atılan bu yöndeki birçok olumlu adıma rağmen geleneksel eğitim modelinin baskın olduğu Türk eğitim sisteminde okul-sanayi iş birliği yeterince sağlanamamış, mesleki eğitim büyük ölçüde teoride kalarak uygulamada sorunlar yaşanmıştır. (MEB, 2006)

Bundan dolayı eğitimde kaliteyi arttırmak, sanayinin katılımını sağlamak ve kullanıcıların istediği nitelikte eleman yetiştirebilmek amacıyla temelleri 1986 yılında atılan 3308 sayılı Çıraklık ve Meslek Eğitimi Kanunu uygulamaya konmuştur. Daha sonra 10/07/2001 tarih ve 4702 sayılı kanunla bazı değişikliklere uğrayan, kanun kapsamı, Mesleki Eğitim Kurulunun belirleyebileceği mesleklerde, bu meslekle ilgili işyerleriyle, mesleki ve teknik eğitim veren okul ve kurumlarındaki eğitim ve öğretimi kapsayacak şekilde geliştirilerek daha esnek bir yapıya kavuşturulmuştur (Anon.2006). Değişiklikler çerçevesinde çıkarılması gereken yönetmelikler, tek yönetmelik halinde Milli Eğitim Bakanlığı'nca hazırlanmış, "Mesleki ve Teknik Eğitim Yönetmeliği” adı altında 03/07/2002 tarih ve 24804 say1l resmi gazetede yayınlanarak yürürlüğe girmiştir (Anon.2002)

$\mathrm{Bu}$ yasa Milli Eğitim Bakanlığı bünyesinde bulunan Endüstri Meslek Liseleri, Ticaret Liseleri, Otelcilik Meslek Liseleri, Teknik Liseler ve K1z Meslek Liselerinde uygulanmaya başlanmıştır.

Yasa gereğince; öğrenci birinci yıl genel kültür derslerinin yanı sıra alanı ile ilgili temel bilgi ve becerileri okulda kazanırken, ikinci ve üçüncü yıllarda, becerilerini gerçek iş ortamında geliştirmektedir. Birinci sınıfta öğrenimini başarıyla tamamlayan öğrenciler, ikinci sınıftan itibaren teorik eğitimlerini haftada iki gün okulda alırken, "İşletmelerde Beceri Eğitimi" olarak programda yer alan uygulamalı derslerinin eğitimini ise haftada üç 
gün işletmelerde yapmaktadırlar (Mesleki ve Teknik Eğitim Yönetmeliği, 2003).

Böylece öğrencilerin bağımsız iş yapabilme, gerçek iş ortamını tanıma, yeni teknolojileri kullanma becerisini geliştirme gibi davranış ve meslek alışkanlıklarını kazanmaları hedeflenmektedir.

$\mathrm{Bu}$ açıdan genç nüfusun yoğun olduğu ülkemizde, insan kaynaklarının verimli bir biçimde kullanılması için ihtiyaç duyulan nitelikte iş gücünü yetiştiren eğitimcilerin, ilgili iş kolları ile iş birliği içinde, 3308 ve 4702 sayılı kanunlar çerçevesinde öngörülen plan ve programlara tam olarak uygun hareket etmesi büyük önem taşımaktadır. Bu da ilgili yönetici ve eğitimcilerin, üstlerine düşen görevleri sorumluluk bilinci ile yerine getirilmeleri ile mümkündür. Çünkü gereği gibi yerine getirilmeyen eğitim programlarından verim almak ve yarar beklemek söz konusu değildir. $\mathrm{Bu}$ noktadan hareketle eğitim çıktısının istihdam girdisini oluşturacağ 1 her iki taraflarca da göz önünde tutulmalıdır.

Uygulamanın amacına ulaşmasında, işletmelerde beceri eğitimine tabi tutulacak öğrencilerin, alacakları eğitime yönelik ön bilgi ve donanımı yeterli düzeyde kazanmas1, kanunun ön gördüğü yükümlülükleri yerine getirmede ilgili tarafların aktif desteği de önem taşımaktadır. Beceri eğitiminin yapılacağı işletmelerin belirlenmesinde de ilgili eğitim kurumları son derece titiz davranmak ve kanunun ön gördüğü şartları yerine getiren kurumları uygulamanın içine almak zorundadır.

Çalışma, 3308 sayılı Mesleki Eğitim Kanunu kapsamında yer alan "işletmelerde beceri eğitimi” uygulamasının amacına ve yönetmelik hükümlerine göre uygulanma düzeyini tespit etmek amacıyla planlanmıştır.

\section{MATERYAL VE YÖNTEM}

Araştırma materyalini Ankara ili merkez ilçelerine bağlı Kız Meslek ve Anadolu Kız Meslek liselerinin Tekstil ve konfeksiyon dalında öğrenim gören, beceri eğitimini hazır giyim işletmelerinde tamamlayan ve tesadüfi örneklem yöntemi ile ulaşılan 4 adet kız meslek lisesi 138 adet son sınıf öğrencisi oluşturmaktadır.

Araştırma verilerinin toplanmasında anket tekniği ve survey yöntemi kullanılmıştır. Anket formunun hazırlanmasında 3308 sayılı Mesleki Eğitim Kanunu ve Mesleki ve Teknik Eğitim Yönetmeliği hükümlerinin İşletmelerde beceri eğitimi uygulama süresine ilişkin kanun maddeleri esas alınmıştır. 
Yapılandırılmış anket formu daha önceden yapılmış bazı araştırmalar, kaynak ve ilgili uzman kişilerin görüşleri doğrultusunda düzenlenmiş, ön deneme sonuçlarının doğrultusunda son şekli verilmiştir (Karasar, 1995, Kaptan, 1993). Veri toplama aracını uygulayabilmek için İl Milli Eğitim Müdürlüğü ve Valilik onayı alınan anket formları, beceri eğitiminin tamamlanması sonrasındaki ilk hafta içersinde, örneklem grubuna uygulanmıştır.

Elde edilen verilerin değerlendirilmesinde SPSS (Statistical Package for Social Science) programından yararlanılmıştır.

Beceri eğitiminin amacına ve yönetmelik hükümlerine göre uygulanma düzeyini ölçmek amacıyla soruların değerlendirilmesinde beşli likert ölçeği kullanılmıştır. Ölçekte yer alan aralıklar eşit olduğundan hareketle, $(4 / 5)=$ 0,80 aralık değeri bulunmuş her bir derece aralığı için bulunan değerler aşağıda sunulmuştur.
Dereceler;
(1) Çok Zayıf
(2)zayıf
(3) Orta
(4) İyi
(5)Çok İyi
Değerler;
$1.00-1,80$
$1,81-2,60$
2,61-3,40 3,41-4,20
$4,21-5,00$

Çalışmada 21 adet sorudan oluşan anket formuna verilen cevapların dağılımına ilişkin veriler, okuyucunun dikkatini dağıtmamak amacıyla tek bir tabloda toplanarak yorumlanmıştır. (Tablo1 a ve b)

\section{BULGULAR VE YORUM}

İşletmelerde yapılan beceri eğitiminin amacına ve yönetmelik hükümlerine göre uygulanma düzeyinin öğrenciler tarafından değerlendirilmesi:

İşletmelerde yapılan beceri eğitiminin amacına ve yönetmelik hükümlerine göre uygulanma düzeyinin öğrenciler tarafindan değerlendirilmesi sonucunda elde edilen verilerin dağılımı tablo 1(a) ve (b)'de yer almaktadır. 
Tablo 1 (a). Isşletmelerde Yapılan Beceri Eğitiminin Amacına ve Yönetmelik Hükümlerine Göre Uygulanma Düzeyi

\begin{tabular}{|c|c|c|c|c|c|c|c|c|c|c|c|c|}
\hline \multirow{3}{*}{$\begin{array}{c}\text { İlgili Kanun } \\
\text { Hükümleri }\end{array}$} & \multicolumn{10}{|c|}{ Katılım Düzeyi } & \multirow{3}{*}{$\mathbf{X}$} & \multirow{3}{*}{ SS } \\
\hline & \multicolumn{2}{|c|}{ Çok zayıf } & \multicolumn{2}{|c|}{ Zaylf } & \multicolumn{2}{|l|}{ Orta } & \multicolumn{2}{|l|}{ İyi } & \multicolumn{2}{|c|}{ Çok iyi } & & \\
\hline & f & $\%$ & f & $\%$ & f & $\%$ & f & $\%$ & f & $\%$ & & \\
\hline $\begin{array}{l}\text { 1. Öğrencilerin } \\
\text { beceri eğitimine } \\
\text { başlamadan önce } \\
\text { mesleki bilgilerin } \\
\text { okulda öğretilmesi }\end{array}$ & 0 & 0,0 & 5 & 3,7 & 42 & 30,9 & 73 & 53,7 & 16 & 11,8 & 3,74 & 0,712 \\
\hline $\begin{array}{l}\text { 2.Seçilen } \\
\text { işletmenin yönetici } \\
\text { tavrı, usta öğretici } \\
\text { yaklaşımı, } \\
\text { işletmenin } \\
\text { teknolojik } \\
\text { imkânları ve yeri } \\
\text { bakımından } \\
\text { değerlendirilmesi } \\
\end{array}$ & 9 & 6,6 & 6 & 4,4 & 27 & 19,9 & 47 & 34,6 & 47 & 34,6 & 3,86 & 1,143 \\
\hline $\begin{array}{l}\text { 3. Okul, işveren, } \\
\text { ögrenci ve veli } \\
\text { arasındaki } \\
\text { yazışma, anlaşma } \\
\text { ve toplantıların } \\
\text { zamanında } \\
\text { yapılması }\end{array}$ & 7 & 5,5 & 11 & 8,6 & 46 & 35,9 & 54 & 42,2 & 10 & 7,8 & 3,38 & 0,948 \\
\hline $\begin{array}{l}\text { 4. Öğrencilerin } \\
\text { sigortalama } \\
\text { işlemlerinin } \\
\text { aksamadan } \\
\text { yapılması }\end{array}$ & 10 & 7,4 & 4 & 2,9 & 20 & 14,7 & 62 & 45,6 & 40 & 29,4 & 3,87 & 1,101 \\
\hline $\begin{array}{l}\text { 5. Öğrencilerin } \\
\text { beceri eğitimi } \\
\text { süresince } \\
\text { öğrenmesi gereken } \\
\text { konuları içeren } \\
\text { öğretim planının } \\
\text { öğretmen } \\
\text { tarafindan } \\
\text { yapılması }\end{array}$ & 5 & 3,7 & 12 & 8,9 & 24 & 17,8 & 70 & 51,9 & 24 & 17,8 & 3,71 & 0,984 \\
\hline $\begin{array}{l}\text { 6. Okul tarafindan } \\
\text { öğrencilere ve } \\
\text { işletmelere beceri } \\
\text { eğitimine ilişkin } \\
\text { rehberliğin } \\
\text { yapılması }\end{array}$ & 7 & 5,1 & 23 & 16,9 & 41 & 30,1 & 49 & 36,0 & 16 & 11,8 & 3,32 & 1,053 \\
\hline $\begin{array}{l}\text { 7. Staj süresince } \\
\text { "bilgi konularının" } \\
\text { işletme } \\
\text { bölümlerine uygun } \\
\text { olarak öğrenciye } \\
\text { kazandırılması }\end{array}$ & 4 & 3,0 & 25 & 18,5 & 30,4 & 29,7 & 56 & 41,5 & 9 & 6,7 & 3,30 & 0,948 \\
\hline
\end{tabular}




\begin{tabular}{|l|c|c|c|c|c|c|c|c|c|c|c|c|}
\hline $\begin{array}{l}8 . \text { Staj süresince } \\
\text { "beceri } \\
\text { konularının" } \\
\text { işletme } \\
\text { bölümlerine uygun } \\
\text { olarak ögrenciye } \\
\text { kazandırılması }\end{array}$ & 5 & 3,7 & 17 & 12,5 & 47 & 34,6 & 51 & 37,5 & 16 & 11,8 & 3,41 & 0,977 \\
\hline $\begin{array}{l}\text { 9. Öğgrencilerin } \\
\text { mesleki } \\
\text { gelişiminin } \\
\text { "gelişim } \\
\text { tablolarıyla" takip } \\
\text { edilmesi }\end{array}$ & 14 & 10,4 & 21 & 15,7 & 31 & 23,1 & 49 & 36,6 & 19 & 14,2 & 3,28 & 1,199 \\
\hline $\begin{array}{l}\text { 10. Öğrencilerin } \\
\text { "işletmedeki } \\
\text { bölümlere" göre } \\
\text { makine ve araç } \\
\text { gereci kullanma } \\
\text { becerisi kazanması }\end{array}$ & 11 & 8,1 & 15 & 11,0 & 29 & 21,3 & 44 & 32,4 & 37 & 27,2 & 3,60 & 1,226 \\
\hline
\end{tabular}

Tablo 1 (b).

İsletmelerde Yapılan Beceri Eğitiminin Amacına ve Yönetmelik Hükümlerine Göre Uygulanma Düzeyi

\begin{tabular}{|c|c|c|c|c|c|c|c|c|c|c|c|c|}
\hline $\begin{array}{l}\text { 11. Öğretilen iş ve } \\
\text { işlemlerin amacına } \\
\text { uygun ve düzenli } \\
\text { aralıklarla usta } \\
\text { öğretici tarafindan } \\
\text { değerlendirilmesi }\end{array}$ & 3 & 2,2 & 18 & 13,3 & 28 & 28,1 & 45 & 33,3 & 31 & 23,0 & 3,61 & 1,051 \\
\hline $\begin{array}{lr}12 . \quad \text { Öğrencilerin } \\
\text { devam } & \text { devam- } \\
\text { devamsızlık } & \\
\text { durumlarının } & \\
\text { işletme } & \text { tarafından } \\
\text { düzenli } & \text { takip } \\
\text { edilmesi } & \\
\end{array}$ & 4 & 3,0 & 5 & 3,7 & 15 & 13,3 & 37 & 27,4 & 71 & 52,6 & 4,23 & 1,014 \\
\hline $\begin{array}{l}\text { 13. Öğrencilerin } \\
\text { resmi gün, bayram } \\
\text { ve tatillerde ücretli } \\
\text { izin haklarından } \\
\text { faydalanması }\end{array}$ & 19 & 14,1 & 18 & 13,3 & 19 & 14,1 & 33 & 24,4 & 46 & 34,1 & 3,51 & 1,434 \\
\hline $\begin{array}{lr}14 . & \text { Öğrencilerin } \\
\text { mesai } & \text { saatlerine } \\
\text { uygun çalıştırılması }\end{array}$ & 10 & 7,5 & 12 & 9,0 & 18 & 13,4 & 32 & 23,9 & 62 & 46,3 & 3,93 & 1,278 \\
\hline $\begin{array}{l}15 . \quad \text { Öğrencilere } \\
\text { çalışma ücretlerinin } \\
\text { hak edilen miktarda } \\
\text { ödenmesi }\end{array}$ & 20 & 14,7 & 19 & 14,0 & 18 & 13,2 & 28 & 20,6 & 51 & 37,5 & 3,52 & 1,476 \\
\hline $\begin{array}{l}\text { 16. Öğrencilerin } \\
\text { işletmenin sosyal } \\
\text { imkânlarından } \\
\text { yararlanması }\end{array}$ & 8 & 5,9 & 15 & 11,1 & 29 & 21,5 & 31 & 23,0 & 52 & 38,5 & 3,77 & 1,240 \\
\hline
\end{tabular}




\begin{tabular}{|c|c|c|c|c|c|c|c|c|c|c|c|c|}
\hline $\begin{array}{l}17 . \quad \text { Okul ve } \\
\text { işletmeler tarafindan } \\
\text { öğrencilerin disiplin } \\
\text { durumunun takip } \\
\text { edilmesi }\end{array}$ & 1 & 0,8 & 11 & 8,5 & 17 & 13,1 & 50 & 38,5 & 51 & 39,2 & 4,07 & 0,966 \\
\hline $\begin{array}{l}\text { 18. Okul tarafindan } \\
\text { eğitimin } \quad \text { etkili } \\
\text { olarak yürütülmesi }\end{array}$ & 4 & 3,0 & 10 & 7,6 & 25 & 18,9 & 64 & 48,5 & 29 & 22,0 & 3,79 & 0,973 \\
\hline $\begin{array}{l}\text { 19. Okul tarafindan } \\
\text { işyerlerinin düzenli } \\
\text { olarak ziyaret } \\
\text { edilmesi ve denetim } \\
\text { çalışmalarının } \\
\text { yürütülmesi }\end{array}$ & 4 & 2,9 & 10 & 7,4 & 24 & 17,6 & 49 & 36,0 & 49 & 36,0 & 3,95 & 1,049 \\
\hline $\begin{array}{l}\text { 20. Veli tarafından } \\
\text { ögrencinin devam - } \\
\text { devamsızlık, başarı } \\
\text { ve disiplin } \\
\text { durumlarının takip } \\
\text { edilmesi }\end{array}$ & 8 & 6,0 & 6 & 4,5 & 23 & 17,3 & 56 & 42,1 & 40 & 30,1 & 3,86 & 1,088 \\
\hline $\begin{array}{l}\text { 21. Okul tarafindan } \\
\text { y1l sonu beceri } \\
\text { sinavları ile öğrenci } \\
\text { değerlendirilmesinin } \\
\text { yapılmas1 }\end{array}$ & 4 & 3,3 & 6 & 4,9 & 19 & 15,6 & 69 & 56,6 & 24 & 19,7 & 3,84 & 0,909 \\
\hline
\end{tabular}

3308 sayılı meslek eğitimi kanununun yönetmelik hükümleri gereğince öğrencilere beceri eğitimine başlamadan önce mesleki bilgilerin öğretilmesi gerekmektedir (M.E.K. Madde 197). Bu maddeye ilişkin tabloda yer alan, "Öğrencilerin beceri eğitimine başlamadan önce mesleki bilgilerin okulda öğretilmesi” konusuna ilişkin 1.no'lu maddeyi öğrencilerin \%53,7'sinin “iyi”" seçeneğinde cevapladığı ve genel ortalamaların da yine bu sınırlar içersinde değiştiği anlaşılmaktadır. $(\mathrm{x}=3.74, \mathrm{SS}=0.712)$ Buda elde edilen değerler göz önüne alındığında öğrencilerin çoğunluğunun mesleki ön bilgileri alarak işletmelere gönderildiğini ortaya koymaktadır.

"Seçilen işletmenin yönetici tavrı, usta öğretici yaklaşımı, işletmenin teknolojik imkânları ve yeri bakımından değerlendirilmesi”" ne ilişkin 2.no'lu madde incelendiğinde ankete katılanların \%69.4' ünün "iyi" ve "çok iyi" seçeneklerinde yoğunlaşmakla birlikte $(\mathrm{x}=3.86, \mathrm{SS}=$ 1.143) ile beceri eğitimi yaptırılan işletmelerin üzerlerine düşen görevleri “iyi” düzeyde gerçekleştirildiği anlaşılmaktadır.

Tabloda iş yerinin işletme belirleme komisyonu tarafından belirlenmesinden sonra ögrenci velisinden onay alınması konusunda "Okul, işveren, öğrenci ve veli arasındaki yazışma, anlaşma ve toplantıların zamanında yapılması" ile ilgili 3.no'lu madde incelendiğinde öğrencilerin \% 42.2' sinin bu tür prosedürün “iyi” düzeyde gerçekleştiği yönünde cevap 
vermekle birlikte genel ortalamanın $(X=3,38, \quad S S=0,948)$ ile "Orta" seçeneğinde yer aldığ 1 dikkati çekmektedir.

Her öğrenci gelecekteki iş yaşamında da kullanmak üzere dönem başında sigorta sicil kartı edinir. Bu nedenle sigorta primlerinin ödenmesi (M.E.K. madde.219) veya ödenmemesi ile ilgili koşulları (M.E.K. madde.224) hakkında yeterli bilgiye sahip olması ve bu koşulların da ilgili kişilere yerine getirilmesi gerekmektedir. Tabloda yer alan " Öğrencilerin sigortalama işlemlerinin aksamadan yapılması' na ilişkin 4.'no lu maddeye öğrencilerin verdikleri cevaplardan bu işlemin $(\mathrm{X}=3.87, \mathrm{SS}=$ 1.101) "iyi” düzeyde gerçekleştiği anlaşılmaktadır.

“Öğrencilerin beceri eğitimi süresince öğrenmesi gereken konuları içeren öğretim planının öğretmen tarafından yapılması” ile ilgili 5.'no lu madde $(\mathrm{X}=3.71, \mathrm{SS}=0.984)$ ile "iyi" düzeyde gerçekleşirken,

"Okul tarafından öğrencilere ve işletmelere beceri eğitimine ilişkin rehberliğin yapılması" konusundaki 6.'no lu madde den elde edilen veriler, bu yükümlülügüü ilgili kişilerce $(X=3.32, \mathrm{SS}=1.053)$ ile "orta" düzeyde gerçekleştirildiğini ortaya koymaktadır.

Yapılan benzer bir çalışmada koordinatör öğretmenlere beceri eğitimine tabi tutulan öğrencilerin eğitimleri süresince yapacakları uygulamalar, çalışacakları işletme departmanları ve üretimde bulunacakları ürünler hakkında bilgi verilip verilmediği sorulmuş, koordinatör öğretmenlerin \%80.4'ü evet, \%15.3'ü kısmen, \%4.3'ü ise hayır cevabını vermişlerdir. (Savaş, 2005)

Her öğrenci meslek alan/dalının öğretim programındaki ilgili sınıfa ait, temrin, iş, proje, deney veya hizmetlerin en az \%80'ini yapmak ve uygulamalardan başarılı olmak zorundadır (M.E.K. madde 183). Bu nedenle öğrenciler beceri eğitimi öncesi öğretim programının amaçları ve içeriği hakkında yeterli bilgiyi kazanmış olmalı ve başarının sağlanması için güdülenmelidir. $\mathrm{Bu}$ bağlamda işletmelerdeki beceri eğitimi mesleki gelişimin güçlenmesi ve güdülenmesi açısından büyük önem taşımakta, gelişim tabloları da bu süreçte öğrencinin öğrendiği iş ve işlemleri işletme bölümlerine uygun olarak kullanıp kullanmadığ 1 ve yeni kazandığ 1 beceri ve bilgileri belirlemek için önemli bir somut veri olmaktadır.

Beceri eğitimi sırasında, öğretim programı içinde yer alan temrin, iş, proje, deney vb. çalışmalardan ne kadarının yaptırıldığı, her öğrenciye ait "Gelişim Tablosu" ile takip edilir. Meslek eğitiminde öğretimin gerçekleştirilebilmesi için bir işlemin kabul edilebilir sayıda tekrarlanması gerekir.(M.E.B.,2004) 
5 ve 6' no lu sorularla bağlantılı olan "Öğrencilerin mesleki gelişiminin, gelişim tablolarıyla takip edilmesi”" ne ilişkin hazırlanan soru maddesi tabloda 9'nolu madde de yer almaktadir. Bu sorudan elde edilen verilerin genel ortalamalarının $(\mathrm{x}=3,28, \mathrm{SS}=1,199)$ ile "orta" değerde yer alması aslında anketleri cevaplayanların \%36.6'l1k bir bölümünün iyi ve \% 14.2'lik kısmının ise çok iyi ölçeğinde toplanmalarına rağmen bu maddeye çok zayıf $\% 10.4$ ve zayıf $\% 15.7$ yönünde cevap verenlerin değerlerinin genel ortalamayı olumsuz yönde etkilemesinden kaynaklanmaktadır.

(Savaş)'ın çalışmasında gelişim değerlendirme formlarını hazırlayarak işletmelere teslim ettiğini belirten koordinatör öğretmenler \%76.2 iken bu formlarla öğrencileri takip eden işletmelerdeki eğitici personel / usta öğreticilerin oranı ise \%65.1 olduğu dikkati çekmektedir.

Mesleki ve Teknik Eğitim Yönetmeliği hükümlerine göre işletmelerde beceri eğitimi uygulaması için belirlenen işletmeler özetle bu işleyişi gerçekleştirecek eğitim ortamını sağlamak zorundadır. Eğitim ortamı, öğrenciye okulda kazandırılan bilgi ve beceriye uygun olarak düzenlenir, gerekli ve yeterli araç-gereç ve teçhizatla donatılır. Eğitim-öğretim teknikleri de ilgili mevzuat hükümlerine göre kurum ile işletme arasında yapılan planlama doğrultusunda yürütülür. Beceri eğitiminin amacına ulaşması açısından bu yönetmelik hükümlerinin tam olarak yerine getirilmesi büyük önem taşımaktadır.(MEB,2002)

Tablo 1(a)'da yönetmelik hükümlerinin ne derece yerine getirildiğini ölçmeye yönelik maddeler, 7,8 ve 10 . sorularda yer almaktadır. 7 . soruda yer alan "Staj süresince işletme bölümlerine uygun olarak "bilgi konuları" nın kazandırılması" na ilişkin öğrencilerin verdikleri cevapların \% 29,7'si "orta" ve \% 41,5'i "iyi" düzeyler de yoğunlaşmakla birlikte, $(X=$ $3,32, \mathrm{SS}=0.948$ ) ile "orta" değerlerde kaldığ dikkati çekmektedir. 8. soruda yer alan "Staj süresince beceri konularının" işletme bölümlerine uygun olarak öğrenciye kazandırılması" na ait bulgulardan öğrencilerin yine, \% 34.6 "sının“orta" ve \% 37.5'inin de "iyi” seçeneklerinde yoğunlaştığ 1 ve elde edilen değerin $(X=3.41, S S=0.977)$ ile "orta" düzeyde olduğu anlaşılmaktadır. Bununla birlikte 10. soruda yer alan, "Öğrencilerin işletmelerdeki bölümlere göre makine-araç-gereci kullanma becerisini kazanma düzeyi" ne ait verilerin $(\mathrm{X}=3,60, \mathrm{SS}=$ 1,226 ) "iyi” düzeyde gerçekleştirildiği dikkati çekmektedir.

Eğitici personel/usta öğretici beceri eğitiminde her öğrencinin, mesleğin özelliğine göre yaptığı temrin, iş, proje, deney veya hizmetin değerlendirilmesini çizelge üzerinde yapar, öğrenci ile birlikte imzalar ve bu dökümanın yer alacağı birer iş dosyası tutmasını sağlar. Tabloda eğitici 
personel/usta öğretici tarafindan bu işlevin yerine getirilip getirilmediğine dair "Öğretilen iş ve işlemlerin amacına uygun ve düzenli aralıklarla usta öğretici tarafından değerlendirilmesi”" konusundaki 10'no lu soruya öğrencilerin \%33.3' ünün “iyi” ve \% 23'nün ise "çok iyi” seçeneklerinde yoğunlaşması ile birlikte ilgili kişilerin $(\mathrm{X}=3.61, \mathrm{SS}=1,051)$ ile "iyi" düzeyde bu görevi yerine getirdiğini göstermektedir.

"Öğrencilerin devam devam-devamsızlık durumlarının işletme tarafindan düzenli takip edilme düzeyi" ne ilişkin hazırlanan 12.soru maddesi öğrencilerin yarısından fazlası tarafından "Çok İyi” seçeneğinde $(\mathrm{X}=4,23, \mathrm{SS}=1,014)$ en yüksek ortalamayla değerlendirilmiştir. 17.soru olan "Okul ve işletmeler tarafından öğrencilerin disiplin durumunun takip edilmesi" ise $(\mathrm{X}=4,07, \mathrm{SS}=0,966)$ "İyi" düzeydedir. "Okul tarafından işyerlerinin düzenli olarak ziyaret edilmesi ve denetim çalışmalarının yürütülmesi" konusundaki 19 . sorununda $(x=3,95, \quad S S=1,049)$ ile yine "iyi” düzeydeki değerleri ortaya koyduğu anlaşılmaktadır.

Elde edilen bulgular, okul ve işletmelerin denetim ve disiplin konusu üzerinde ciddiyetle durduklarını ve olabildiğince bu düzenlemeleri aksatmadıklarını ortaya koymaktadır.

Bölükbaşı (2004) tarafından gerçekleştirilen yüksek lisans çalışmasında 16 K.M.L.'nin giyim bölümü koordinatör öğretmenlerine yöneltilen bu konudaki sorular incelendiğinde, öğretmenlerin $(2,60-3,39)$ sinırları içersinde, $(X=2,68, S S=1,25)$ “orta” düzeyde öğrencileri işyerinde gözlemledikleri tespit edilmiştir. Öğrencileri yerinde düzenli olarak ziyaret etme düzeylerinin de yine aynı sınırlar içerisinde $(X=2,74, \mathrm{SS}=1,21)$ ile "orta” düzeyde gerçekleştiği ortaya çıkmıştır.

3308 sayılı Mesleki eğitim Kanununa göre; mesleki ve teknik öğretim kurumlarındaki meslek dersi öğretmenlerinin okul-işletme işbirliğinde ortaklaşa yürütülen meslek eğitiminde "koordinatör öğretmen" görevini üstlenenlerin, denetim, disiplin ve gözlem konusunda görev almalarını öngörülmektedir (Doğan, Ulusoy, ve Hacioğlu;1997). Koordinatör öğretmenlerin, işletmede beceri eğitimi gören öğrencilerin karşılaştıkları zorunluluklarla ilgilenme ve bu sorunların çözümünde etkin sorumluluk almaları gerekmektedir. Bölükbaşı'nın (2004) elde ettiği sonuçlar ile bu çalışmada elde edilen veriler karşılaştırıldığında zamanla konuya verilen önemin daha da $\operatorname{arttığı~ve~ilgililerin~daha~da~bilinçlendiğini~söylemek~}$ mümkündür.

Öğrenci başarısında ailelerinde büyük payı olduğu yadsınamaz bir gerçektir. Tabloda yer alan 20'nolu madde de "Veli tarafından öğrencinin devam -devamsızlık, başarı ve disiplin durumlarının takip edilmesi”" ne 
ilişskin veriler $(x=3,86, S S=1,088)$ ile velilerin kendilerine düşen bu görevi "iyi” düzeyde yerine getirdiğini göstermektedir.

Öğrencilerin işletmelerdeki beceri eğitiminin sonunda bağlı olduğu okul tarafindan yılsonu beceri sinavina tabi tutulması ve bu bağlamda dönem sonundan beş gün önce öğrencilerin ilgili döneme ait puan çizelgelerini kapalı zarf içinde okul müdürlüklerine teslim etmesi gerekmektedir. (M.E.K. Madde 196) Öğrencilerin başarılı - başarısızlıklarının belirlenmesi için yapılan yıl sonu beceri eğitimi sınavı, ayrıca öğrenciler tarafından tutulan iş dosyaları ve işletmelerden gelen bu puan çizelgeleri ile birlikte değerlendirilmektedir.Tabloda yer alan "Okul tarafindan yılsonu beceri sınavları ile öğrenci değerlendirilmesinin yapılması”" na ilişkin 21. maddeye ögrencilerin verdikleri cevaplar $(x=3,84, \quad S S=0.909)$ ile "iyi" düzeyde kaldığ1 , öğrencilerin \%3.3 "çok zayıf" ve \%4.9'unun ise bu yükümlülüğün okullar tarafından "zayıf” düzeyde gerçekleştirildiğini ortaya koyması dikkat çekicidir.

\section{SONUÇ}

Tablo 1 (a) ve (b) genel olarak incelendiğinde işletmelerde yapılan beceri eğitiminin amacına ve yönetmelik hükümlerine göre uygulanma düzeyine ilişkin olarak hazırlanan soru maddelerinin çoğunluluğunun öğrenciler tarafından değerlendirilmesi "iyi" düzeyi sınırlarında kaldığı anlaşılmaktadır.

Ancak bununla birlikte, okul, işveren, öğrenci ve veli arasındaki yazışma, anlaşma ve toplantıların zamanında yapılması, okul tarafından öğrencilere ve işletmelere beceri eğitimine ilişkin rehberliğin yapılması, staj süresince "bilgi konularının" işletme bölümlerine uygun olarak öğrenciye kazandırılması, öğrencilerin mesleki gelişiminin "gelişim tablolarıyla" takip edilmesi ve öğrencilerin devam devam-devamsızlık durumlarının işletme tarafindan düzenli takip edilmesi konularında verilen cevapların ortalamalarının "orta" düzeyde yer alması, beceri eğitimi süresince bazı yükümlülüklerin yeterince dikkatli üstlenilmediğini de ortaya koymaktadır.

Ülkemizde önemi gün geçtikçe daha da iyi anlaşlan mesleki eğitim uygulamaları, halen tam olarak bir düzene oturmamış olmakla birlikte, mesleki niteliklerin belirlenmesi, mesleğin edinilmesine yönelik eğitim verilmesi ve bu eğitimin belgelendirilmesine dair çalışmalar büyük bir kararl1l1kla sürdürülmektedir.

Çünkü milli eğitim sistemi içerinde çok önemli bir yere sahip olan mesleki ve teknik eğitim veren okulların, uluslararası meslek standartlarını ele alarak programlarını akredite etmeleri, denetim, ölçme ve değerlendirme, 
belgelendirme ve sertifikalandırmaya ilişkin faaliyetlerle eğitim-öğretimişgücü-istihdam ilişkisini daha sağlam temellere oturtmaları gerekmektedir.

$\mathrm{Bu}$ bağlamda Meslek liselerinin önemli bir eğitim-öğretim sürecini kapsayan beceri eğitiminin mezuniyet sonrasında hem tekstil ve hazır giyim sektörünün ihtiyaçlarını karşılayacak nitelikte olması, hem de bu eğitimin meyvelerinin çok daha detaylı hazırlanmış diploma eki ile belgeli olarak mezunların elinde yer alması da onların önünü açacaktır.

$\mathrm{AB}$ ülkelerinde çalışma hayatı ile eğitim arasındaki ilişkinin kurulmasında mesleki yeterlilikler, sınav ve belgelendirme sistemleri önemli işlevler görmektedir. Ülkemizde de birçok mesleğe ilişkin düzenlemeleri gerçekleştirebilecek bir kurum olarak çalışmalarına başlayan Mesleki Yeterlilikler Kurumu, A.B. üyelik sürecinden gerekli faydanın sağlanması ve yeni bir yapılanmada önemli rol oynayacaktır.

Ülkemiz için yadsınamaz bir potansiyeli içinde barındıran tekstil ve hazır giyim sektörüne ara iş gücünü sağlayan kız meslek ve Anadolu kız meslek liselerinin çok daha dikkatle ele alınması gerekmektedir. İlgili düzenlemelerin en kısa zamanda tamamlanarak sanayi ile iş birliği çerçevesinde yürürlüğe konması her iki tarafa da fayda sağlayacağı göz önüne alınarak;

Beceri eğitimi yaptırılacak işletmelerin titizlikle kanuna uygun ölçütlerde seçilmesi ve koordinatör öğretmenlere izleyebilecekleri sayıda öğrenci sorumluluğu verilmesi önem taşımaktadır. Öğrencilere beceri eğitimine başlamadan önce, uygulama sırasında karşılaşacakları durumlarla ilgili yeterli düzeyde rehberlik yapılmasıyla uygulamanın amacına ulaşması sağlanmalıdır. Teknolojik donanımı yeterli işletmelerin söz konusu eğitimde tercih edilmesi, kanunla ilgili yasal uygulamalara uyulup uyulmadığı konusunda ilgili kurumlar tarafindan denetimlerin sistemli bir biçimde gerçekleştirilmesi takip edilmelidir. Ayrıca öğrencilerin çalıştıkları işletmelerde mezun olduktan sonra istihdam edilmesini kolaylaştırıcı düzenlemelerin yapılması da önerilebilir.

\section{KAYNAKLAR}

Anon. (2006,31 Aralık) . Mesleki Eğitim Kanunu Esnetildi. İşte İnsan İlavesi, Sabah Gazetesi . s. 2.

Anon. (03/07/2002 ) "Mesleki ve Teknik Eğitim Yönetmeliğì" (M.E.B. 4702 Sayılı Kanun) . 24804 sayılı resmi gazete. 
Bölükbașı, A. (2004). Kız Teknik Öğretim Okulları Tekstil-Konfeksiyon Alanı Öğretim Programında Kazandırılan Teknik Bilgi ve Becerilerin İs Hayatındaki Uygulamalarla Tutarlılı̆̆ , Yayınlanmamış Yüksek Lisans Tezi, Gazi Üniversitesi. Ankara.

Doğan, H, Ulusoy, A, ve Hacıoğlu, F. (1997), Okul Sanayi İlişkileri. Ankara.

Kaptan, S. (1993). Bilimsel Araştırma ve İstatistik Teknikler., Ankara. Tek 1ş1k Web Ofset. s;59

Karasar, N. (1995). Araştırmalarda Rapor Hazırlama. Ankara: Araştırma eğitim Danışmanlık L.T.D.,s;12

Savaş, D. (2005). Işsletmelerde Beceri Eğitiminin 3308 Sayll Meslek Eğitimi Kanununa Uygun Gerçekleştirilme Düzeyi. Yayınlanmamış Yüksek Lisans Tezi. Gazi Üniversitesi. Ankara.

TC. Milli Eğitim Bakanlığı (2002), Mesleki ve Teknik Eğitim Yönetmeliği hükümleri 2539 Say1lı Ağustos MEB Tebliğler Dergisi.

TC. Milli Eğitim Bakanlığı (2003), Çıraklık ve Mesleki Eğitim Kanunu. Ankara; Milli Eğitim Basımevi

TC. Milli Eğitim Bakanlığı (2004). Işsletmelerde Meslek Ĕgitimi Öğrenci Iss Dosyası. (M.E.B.IŞ Dosyası). Ankara: Anadolu Okul Yayınları

TC.Milli Eğitim Bakanlığı (MEK maddeleri) (20.02.2006) "Mesleki ve Teknik Eğitim Yönetmeliği” http:// www.meb.gov.tr .(12.01. 2008)

TC.Milli Eğitim Bakanlığ $\quad$ (08.03.2006) B.08.0.Kız Teknik Öğretim.0.1.1.01.02-510/43/8592 sayılı Genelgesi, Okul ve Işsletmelerde Mesleki Eğitim.www.memurlar.net (07.09.2007) 